\title{
Cities and villages in the religious conflict circle: Socio-demographic factors of communal and sectarian conflict in West Java, Indonesia
}

Author:
Adon N. Jamaludin ${ }^{1}$
Affiliation:
'Department of Sociology,
Faculty of Social and Political
Sciences, Islamic State
University Sunan Gunung
Djati, Bandung, Indonesia
Corresponding author:
Adon Jamaludin,
adon270372@uinsgd.ac.id
Dates:
Received: 20 May 2021
Accepted: 04 Sept. 2021
Published: 03 Nov. 2021
How to cite this article:
Read online:
Jamaludin, A.N., 2021, 'Cities
and villages in the religious
conflict circle: Socio-
demographic factors of
communal and sectarian
mobile device
to read online.
conflict in West Java,
Indonesia', HTS Teologiese
Studies/Theological Studies
77(4), a6854. https://doi.
org/10.4102/hts.v77i4.6854
Copyright:
(c) 2021. The Authors.
Licensee: AOSIS. This work
is licensed under the
Creative Commons
Attribution License.

This article analyses the forms of religious conflict in cities (urban areas) and villages (rural areas) in Indonesia. The main locus of this study is in 11 regencies and cities in West Java, a province with the highest ranking of violations of religious freedom in Indonesia for the last two decades (2000-2020). These regencies and cities include: Bekasi Regency, Bekasi City, Bogor Regency, Bogor City, Tasikmalaya Regency, Bandung Regency, Bandung City, Kuningan Regency, Garut Regency, Cianjur Regency and Cimahi City. The study confirms that the sociological characteristics of urban and rural areas influence the tendency of different forms of conflict in both areas. On the one hand, heterogeneous urban social conditions tend to have an impact on the forms of conflict between religious communities - Muslims and Christians. On the other hand, the homogeneous rural social conditions affect the forms of conflict that are internal to religious communities or fellow Muslims. This study shows that religious conflict in a region cannot be generalised because each region has different socio-demographic conditions. Therefore, knowledge of differences in socio-demographic conditions in each region is very important because it will determine the form, causes and the ways to handle the conflicts in each region.

Contribution: This study contributes to mapping the different sociological characteristics of religious conflict in cities and villages in West Java. It can be used as an illustration for other regions in Indonesia and Southeast Asia.

Keywords: conflict; religion; city; village; West Java.

\section{Introduction}

West Java province in Indonesia has the highest number of violations of freedom of religious expression and beliefs. Several survey institutions such as the Wahid Institute, the Setara Institute, Center for Religious and Cross-Cultural Studies (CRCS) and the National Commission on Human Rights have been announcing the results amidst the increasing number of cases of these violations over the last two decades (2000-2020). Based on data from the Wahid Institute in 2015 and the Setara Institute in 2016, there has been an increase in violations of religious freedom compared with previous years. Both institutes ranked West Java as the area with the highest number of violations and consequently it was labelled the most intolerant province in Indonesia (CRCS 2011, 2013; Setara Institute 2014, 2016:2; The Wahid Institute 2015:32).

The results of this survey are in line with the findings of scholars (Bagir 2014; Marshall 2018). Several scholars have previously even stated that West Java is one of the areas where radicalism and terrorism are seeded in Indonesia. This is related to the high level of poverty in this area, the open Sundanese culture and the shadow of the Darul Islam/Tentara Islam Indonesia (DI/TII) movement in the past (Djelantik 2006; Horikoshi 1987; Mudzakkir 2008; Newland 2000; Syukur 2011).

However, many surveys on freedom of religion and belief conducted by several institutions during the last two decades tend to generalise into numbers without looking at the diversity of sociodemographic conditions in each of these regions. The high number of violations of religious freedom in West Java is only based on the number of incidents of communal and sectarian conflicts without looking more deeply at the socio-demographic conditions where each case occurs.

This study is different from previous research. It is important to consider that religious conflict in West Java must be related to the sociological characteristics of urban and rural areas in each conflict area. In this study, the definition of religious conflict is understood as a feud concerning 
status, power and resources involving religious issues or issues framed in religious slogans or expressions (Ali Fauzi, Alam \& Panggabean 2009:7). It is related to sociodemographic factors in which differences in urban and rural sociological characteristics cannot be separated from economic determination factors. The socio-demographic conditions greatly influence the tendency of different forms of conflict in each region. The urban social conditions (urban), which are heterogeneous, multi-religious and ethnic, for example, have an impact on the form of communal conflicts amongst religious groups between Muslims and Christians such as in the Ambon and Poso cases in 2000-2002 (Dandirwalu \& Rehy 2020; Iqbal 2015:237). On the other hand, the homogeneous rural social condition (rural) affects the form of internal sectarian conflict amongst religious communities or fellow Muslims, as seen in the case of Ahmadiyah in Cikeusik in 2011 (Scherpen 2011). This study is important to show that various religious conflicts in different regions in Indonesia are closely related to the sociodemographic conditions of each region.

Based on Toennis' category, strong individuality amid high immigrants causes urban communities (gesellchaft) to have high levels of contact with interfaith adherents. It is in contrast to rural communities (gemeinschaft), which have intimate family relationships. The unity of morality and religion makes contact with various religions less prominent than internal religious adherents (Stolley 2005:169; Toennies 1963). So, the tendency of the conflict in each case is different. The socio-demographic conditions of religious adherents influence it. Thus, knowledge of differences in sociodemographic conditions in each region is very important because it will determine the form, causes and conflicts handling in each region.

This study focuses on the socio-demographic aspect as a point of view in analysing religious conflict in West Java. The 11 districts or cities which are the locus of this research include: Bekasi Regency, Bekasi City, Bogor Regency, Bogor City, Cianjur Regency, Bandung regency, Bandung City, Cimahi City, Garut Regency, Tasikmalaya Regency and Kuningan Regency. These 11 regions have a high level of religious conflict. A series of observations and interviews for data collection were carried out, especially with the Forum Kerukunan Umat Beragama (Religious Harmony Forum) at the provincial and regency/city levels in Indonesia. The data analysis used is a qualitative approach through data display, data reduction, interpretation and conclusion.

Several previous studies did not consider socio-demographic factors in analysing religious conflict in West Java. Marshall's study, for example, asked why this area became home to some of the greatest acts of intolerance in Indonesia. Does it reflect a different cultural pattern from the Sundanese people who mostly live there or show the tensions produced by modernisation that have created many conflicts in the world? (Marshall 2018). Other previous studies (Sulistio 2018) on intolerance acts in church construction cases in Bekasi also did not consider this socio-demographic factor. So did the scholars examining attacks on Ahmadiyah, Shia, Gafatar and other minority groups in West Java (Burhani 2020; Makin 2019; Nurdin \& Kharlie 2019; Zulkifli 2009).

\section{Religious conflict in West Java}

Lewis Coser referred to conflict as 'a struggle over values and claims to secure status, power and resources, a struggle in which the main aims of opponents are to neutralize, injure or eliminate rivals' (Coser 1956). For the purpose this study, religious conflict is defined as a feud concerning status, power and resources involving religious issues or issues framed in religious slogans or expressions (Ali Fauzi et al. 2009:7). It is related to socio-demographic factors in which differences in urban and rural sociological characteristics are strongly influenced by economic determination factors. The city as an economic and trade centre affects the diversity of its people so that it has an impact on forms of communal conflict amongst religious people. In contrast, the rural areas tend to be homogeneous and affect the sectarian internal conflict amongst the religious people or fellow Muslims.

For more than a decade, a series of religious conflicts and violence has continued in Indonesia. The Setara Institute data show a increased tendency of cases of violations of religious freedom and belief in Indonesia. During January-June 2016, Setara Institute recorded 62 cases of violations spread across 18 provinces. Moreover, the Wahid Institute data recorded up to 190 cases of violations in 2016. There is an increase of 20\% compared with 158 cases of violations in 2014 (The Wahid Institute 2015).

Based on these above mentioned reports, West Java Province ranks the highest with the highest number of violations, becoming the most intolerant area in Indonesia. The Setara Institute data mention that out of the 62 cases in Indonesia, 13 cases of violations were recorded in West Java. The rest happened in a number of other provinces. Whilst the Wahid Institute data show that out of the 190 cases of violations, 46 cases were from West Java (The Wahid Institute 2015). The rest are spread over in other provinces, such as Aceh (36 cases), DKI Jakarta (23), Yogyakarta (10), East Java (9), Lampung (8), Banten (7) and Central Java (7). Some cases of such violations occurred in the attack on the Ahmadiyah community in Manis Lor, Tasikmalaya, Garut, Cianjur and others.

The question that arises is why does West Java province ranks the highest in cases of violations of religious freedom and belief in Indonesia, whereas inhabited by Sundanese it is known as one of the areas rich in traditional values and local wisdom in Indonesia. Many local Sundanese wisdom that shows the heritage of traditional values are reflected in the expressions such as: silih asih, silih asah, silih asuh [loving each other, giving knowledge and nurturing each other amongst the community]; herang caina beunang laukna [solving problems without causing new problems]; $k a$ cai 
TABLE 1: Religious areas prone to conflicts in West Java.

\begin{tabular}{llll}
\hline No. & Human Rights Commission & Setara Institute & Wahid Institute \\
\hline 1 & Bogor City & Bogor Regency/City & Kota Depok City \\
2 & Bandung City & Sukabumi Regency/City & Bogor Regency/City \\
3 & Bekasi City & Bandung Regency/City & Sukabumi Regency/City \\
4 & Kuningan Regency & Bekasi Regency/City & Bandung Regency/City \\
5 & Cianjur Regency & Tasikmalaya Regency & Bekasi Regency/City Rency/City \\
6 & Tasikmalaya Regency & Kuningan Regency & Cirebon Regency Rency/City \\
7 & - & Subang Regency & Banjar Regency/City \\
8 & - & Cianjur Regency & Tasikmalaya Regency \\
9 & - & Depok City & Kuningan Regency \\
10 & - & Karawang Regency & Purwakarta Regency \\
\hline 11 & - & Indramayu Regency & -
\end{tabular}

Sources: Setara Institute, 2016, Laporan Tengah Tahun Kondisi Kebebasan Beragama/ Berkeyakinan di Indonesia Januari-Juni 2016, Setara Institute, Jakarta; The Wahid Institute, 2015, Laporan Akhir Tahun Kebebasan Beragama/Berkeyakinan 2015, The Wahid Institute, Jakarta; CRCS, 2013, Laporan Tahunan Kehidupan Beragama di Indonesia 2012, Center for Religious and Cross-Cultural Studies, Gadjah Mada University, Yogyakarta.

CRCS, Center for Religious and Cross-Cultural Studies.

jadi saleuwi ka darat jadi salogak [achieving mutually beneficial goals] and others.

Sociologically, the increase in cases of such violations is not only related to the religious doctrine but also the situation of social change in West Java. The shift of culture and social structure from village to city and from agrarian to industrial, impacts the lives of its increasingly heterogeneous people. As an area adjacent to the nation's capital, DKI Jakarta, the presence of migrants from various regions in Indonesia and abroad is inevitable.

As an ethnically and religiously heterogeneous region, West Java is known for a variety of potential conflicts. Uncontrolled displacement has been one of the triggering factors for internal and interfaith conflicts. The high level of migration germinates competition and friction that leads to the dominance of immigrant groups in the economic field. It creates an inequal social relationship between migrants and local residents, thus triggering potential social conflicts (Iqbal 2015:237).

There have been a number of cases of social conflict in West Java over the last two decades since the reform era in 1998. A number of cases of socio-religious conflicts, either internal or interfaith, are in the case of houses of worship, religious understanding, blasphemy, conflicts of interest of religious leaders and demonstrations of religious attributes (Ali 2013:248249). Cases of houses of worship appear evenly in almost all areas of the city/regency in West Java in the form of the use of residences or businesses as houses of worship and rejection of citizens to other religious houses of worship and the issue of Christianisation. Certain religious issues develop in the internal environment of mainstream religion. Blasphemy occurs in the case of banning prayers, wearing of headscarves, destruction of statues of Mother Mary, religious insults and others. Conflicts of interest of religious leaders occur amongst Muslims and Christians resulting in conflicts between both supporters. Whilst religious demonstrations involving the masses along with violent acts committed against entertainment venues, support for the enforcement of sharia local regulations, political competition in elections and others. Table 1 details some of the areas prone to religious conflict in West Java over the last two decades based on data from socio-religious research institutes.

Table 1 shows a number of regencies/cities in West Java as the place where cases of religious conflict occur. There are two different locus tendencies, namely regencies and cities. The next section will be directed at the analysis of the spread of religious conflicts in West Java based on the differences between the two locales. The explanation is useful to clearly map the differences in conflict characteristics in the two areas so that a better understanding is obtained.

\section{Town and village characteristics in religious conflict}

There are two main areas in this article, namely regencies and cities in West Java. Both have different potential for religious conflict. Geographically, cities have a higher level of population heterogeneity than regencies. Cities tend to be more plural and heterogeneous ethnically and in custom. The attitude of urban people tends to be individualistic, rational, thus leading to secularity. Homogeneous religious ties are not particularly prominent. The position of religious leaders is also not too dominant. Therefore, in urban areas, religious homogeneity tends to decrease, and heterogeneity and religious freedom tend to be high. Religious adherents and types of worship places are also very diverse. Besides, the lifestyle and social system of the urban community have also undergone a shift. As a result of the high level of population density, there is a change in land use in urban areas that has resulted in smaller availability of land.

Socio-anthropologically, urban areas in West Java have been transformed into cultural faults, where socio-religious groups from various religions meet because of their high level of urbanisation. In these areas, there are diverse elements of social class (strata), ethnicity, religion, culture, customs, language and gender, and people tend to live independently without mixing each other (Nasikun 1986:31).

It is in contrast with rural areas, where the level of community homogeneity is very dominant. In rural areas, indigenous people are the dominant inhabitants because migration from 
TABLE 2: Salient characteristics of the rural and urban areas.

\begin{tabular}{|c|c|}
\hline Rural & Urban \\
\hline 1. It has high homogeneity. & 1. The heterogeneity is quite high. \\
\hline $\begin{array}{l}\text { 2. The norms and customs are still very } \\
\text { sticky and strong. }\end{array}$ & 2. It has very high religious diversity. \\
\hline 3. Religious diversity is still very limited. & 3. It has a high population density. \\
\hline $\begin{array}{l}\text { 4. The population density is still small } \\
\text { compared with other areas. }\end{array}$ & $\begin{array}{l}\text { 4. The cultural patterns and behaviour of } \\
\text { newcomers vary. }\end{array}$ \\
\hline $\begin{array}{l}\text { 5. The role of local community leaders, } \\
\text { including clerics and other religious } \\
\text { groups, still dominates the behaviour } \\
\text { and attitudes of the community. }\end{array}$ & $\begin{array}{l}\text { 5. The community is more open, rational } \\
\text { and high tolerance. }\end{array}$ \\
\hline - & $\begin{array}{l}\text { 6. They are the economic centres and } \\
\text { centres of trade and services. }\end{array}$ \\
\hline- & $\begin{array}{l}\text { 7. The community is more focused on } \\
\text { economic and business activities. }\end{array}$ \\
\hline
\end{tabular}

Source: Nasikun, 1986, Sistem Sosial Indonesia, Rajawali Press, Jakarta

outside the area rarely occurs. Norms and customs are strongly attached to the lives of the people. Their way of thinking generally tends to be passive and irrational. The values of sacredness and religiosity are still very high. Generally, religious diversity is very limited and a homogeneous population density is still visible compared with other regions. On the other hand, the role of local community leaders, including ulama, still dominates the behaviour and attitudes of the community. Table 2 shows the different characteristics of the rural and urban areas.

The social differences between villages and cities have an influence on the characteristics of different religious conflicts in both the areas. M. Rifa'i and M. Rafani Akhyar (Interview, Bandung, West Java, June 05, 2018) confirmed that conflicts between religious communities generally occur in urban areas, whilst internal conflicts within religious communities generally occur in rural areas. The regencies of Garut, Tasikmalaya, Bandung, Cianjur, Bogor, Bekasi and Kuningan are representative of rural areas that have had internal religious conflicts and sectarianism amongst Muslims. The rural regencies tend to be homogeneous and are entirely inhabited by Muslims. Therefore, the internal conflicts amongst Muslims dominate in rural areas.

A point in case are the religious conflicts between antiAhmadiyah Islamic organisations and Ahmadiyah groups in Manislor Kuningan, Tenjowaringin Tasikmalaya and Cianjur, that occurred after the issuance of the Fatwa of the Indonesian Ulama Council in 2010 (Burhani 2014). In addition to Ahmadiyah cases, religious conflicts also occurred between the Anti-Shia National Alliance, that represents Sunni Islam, and the followers of Shia Islam in Bogor, Bandung and several other areas in West Java (Syarif, Zulkarnain \& Sofjan 2017). Conflicts that occur internally amongst a group of fellow Muslims or Ahmadiyah and Shia groups generally occur in rural areas which are predominately inhabited by homogeneous religious adherents.

Internal religious conflicts in rural areas are different from religious conflicts that occur in urban areas. Geographically, the cities have a higher level of population heterogeneity compared to regencies. Urban areas tend to be more ethnically and religiously plural. Therefore, the prominent religious conflicts in urban areas are communal conflicts between religious communities such as in the case of the construction of the HKBP Filadelfia house of worship in Bekasi and Buddhist and Hindu houses of worship in 2019. Therefore, the socio-demographic factors of the village community and cities in West Java are one of the important factors that distinguish the characteristics of religious conflict in various regions in West Java.

\section{Communal and sectarian issues in villages and cities}

Generally, the characters of religious conflict in West Java cannot be separated from the issue of religious identity that is framed in religious slogans or expressions. The religious issues are indisputably related to the teachings or doctrines of a religion. Meanwhile, the issue framed in religious slogans or expressions are more general issues that are regarded to have a connection with their religious teachings or doctrines.

Many religious issues have emerged during the various religious conflicts that have occurred in West Java, for example, moral, sectarian, communal, terrorist, politicoreligious and the mystical religious subculture issues such as witchcraft, divination and so on (Ali Fauzi et al. 2009:9-10). Out of these religious issues, sectarian and communal issues are the two most prominent issues in the 11 regencies and cities in West Java.

Sectarian issues of religious sect within the Muslim community that developed in West Java are: Ahmadiyah, Shia, al-Qiyadah al-Islamiyah, Wahabi, Salamullah, Islam Jamaah/Lembaga Dakwah Islam Indonesia/Indonesian Islamic Da'wah Institute (LDII), Darul Arqam, Inkar Sunnah, Satrio Piningit, Mahesa Kurung, Isa Bugis, Gafatar, the Nubuwah Sangga Buana sect and others. Generally, sectarian issues develops in regencies such as: Bekasi, Bogor, Cianjur, Bandung, Garut, Tasikmalaya and Kuningan. Meanwhile, communal issues that occur are the issue of building places of worship such as Gereja Kristen Indonesia (GKI) or the Indonesian Christian Church, Yasmin Bogor in Bogor City (see Table 2).

Table 3 shows that internal sectarian issues of Muslims tend to develop in regencies but communal issues are more prevalent in cities. This confirms that the urban and rural sociodemographic conditions influence the tendency of different forms of conflicts in their respective regions. Heterogeneous urban social conditions tend to have an impact on the form of communal conflicts between Muslims and Christians, such as in the case of GKI Yasmin in Bogor. On the other hand, homogeneous rural social conditions affect the internal forms of sectarian conflict amongst religious communities or fellow Muslims as manifested by the Ahmadiyah case in Tasikmalaya, Garut, Kuningan and Cianjur.

As previously explained, the characteristics of urban areas are high urbanisation and social, economic, cultural and religious heterogeneity. Religious diversity in urban areas occurs along with the heterogeneity of the population itself. 
TABLE 3: Religious issues in regencies and cities.

\begin{tabular}{|c|c|c|}
\hline No & Regency/city & Religious issues \\
\hline 1. & Bekasi Regency & $\begin{array}{l}\text { Nubuwah Sangga Buana sect in Cibitung, Tarumajaya } \\
\text { and Kedungwaringin }\end{array}$ \\
\hline 2. & Bekasi City & The building of worship places \\
\hline 3. & Bogor Regency & $\begin{array}{l}\text { Sects of al-Qiyadah al-Islamiyah, Ahmadiyah, } \\
\text { Salamullah, Islam Jamaah, Shia, Darul Arqam, Inkar } \\
\text { Sunnah, Satrio Piningit, Mahesa Kurung, Pajajaran } \\
\text { Siliwangi Panjalu, Isa Bugis and Gafatar }\end{array}$ \\
\hline 4. & Bogor City & Permittance to establish the GKI Yasmin \\
\hline 5. & Cianjur Regency & $\begin{array}{l}\text { Ahmadiyah Jamaah, Wahabi Islamic Boarding School } \\
\text { and the Anti-Speaker (Aspect) Islamic Community }\end{array}$ \\
\hline 6. & Bandung Regency & $\begin{array}{l}\text { Ahmadiyah, Shia, Aliran Kebatinan Perjalanan (AKP or } \\
\text { the Mysticism School of Journey), Agama Kuring, } \\
\text { Sabandar Karimandi, Islam Jamaah/LDII, Tarekat } \\
\text { Qadiriyah Kadirun Yahya, Mang Marna sect, Imam } \\
\text { Mahdi, Pondok Rasul, Baha'i and Amanat Keagungan } \\
\text { Ilahi (AKI or the Mandate of Divine Greatness) }\end{array}$ \\
\hline 7. & Bandung City & The building of worship places \\
\hline 8. & Cimahi City & The building of worship places \\
\hline 9. & Garut Regency & $\begin{array}{l}\text { Ahmadiyah Cilawu, Sensen Komara Bakar Misbah and } \\
\text { Tajkia sect }\end{array}$ \\
\hline 10. & Tasikmalaya Regency & Ahmadiyah Singaparna and Salawu \\
\hline 11. & Kuningan Regency & Ahmadiyah Manislor \\
\hline
\end{tabular}

Sources: The result of direct observation in several regencies and cities in West Java, MayJune 2018

Therefore, it is justifiable that it also affects the religious diversity and the intensity of the construction of worship places such as churches. For instance, the case of communal conflicts between Muslims and Christians related to the construction of churches such as GKI Yasmin Bogor. The Muslims who opposed the construction of the church questioned the permit of construction, the use of public facilities for worship places, the residents' protests and the revocation of the permit for the worship place.

Religious conflicts in urban areas related to the construction of worship places continue to occur even though the Indonesian government has established SKB No.1/Ber/ MDN-MAG/1969 concerning the implementation of government apparatus duties in ensuring order and smooth implementation of religious development and worship by its adherents and the Joint Regulation of the Minister of Religion and the Minister of Home Affairs Number 8 of 2006 and Number 9 of 2006 concerning Guidelines for Implementation of Tasks Regional Heads/Deputy Regional Heads in maintaining Religious Harmony, Empowering Religious Harmony Forums and establishing houses of worship (Rumadi 2007:10-11). This is partly because the regulations have multiple interpretations regarding who the local government is, the government officials who are empowered to do so, and the religious organisations and the local ulama or clergy (Kustini 2009:2). Thus, the regulations made it more difficult for minorities to obtain rightful permission to build places of worship.

The communal religious conflicts in urban areas are different from the internal sectarian conflicts amongst Muslims, which generally occur in rural areas. The villages are characterised by the dominance of the community pattern; the homogeneity of religion, customs and traditions that become the norm; highly respected community leaders or figures; and a tendency to reject new things. Therefore, the internal sectarian issues of Muslims have become very prominent in rural areas. It is a result of the interpretation or understanding of teachings in Islam as seen in the case of Ahmadiyah, Shia and other sects.

According to Azyumardi Azra, the development of various sects or religious understandings that are different from the mainstream teachings in Islam occurs amidst socio-economic changes as a result of globalisation, which causes psychological disorientation or dislocation in the society (Azra 1999:10). Dissatisfaction with religious ideologies, movements or organisations that do not accommodate their spiritual needs also encourage the emergence of sectarianism in the Muslim community. There has also been a decline in the credibility of religious leaders amongst the people because of the influence of activities in the political world. Apart from this, one of the prominent symptoms in several movements is that their education and religious knowledge aspects are relatively minimal but they are balanced with a high religious spirit (Van Bruinessen 1999:242, 2004:230). It is understandable considering that low education and poverty are amongst the main problems of rural communities.

Furthermore, differences in patterns of religious conflict in rural and urban areas of West Java also indirectly influence the forms of conflict resolution. In rural areas, generally, dialogue between religious leaders and local communities can resolve internal Muslim conflicts such as in the Ahmadiyah case. In general, Ahmadiyah followers and other Muslims have great respect for religious and local community leaders. Thus, to resolve the conflict, they do as in Ahmadiyah case in Kuningan and Garut. The government through the Ministry of Religion, Kantor Urusan Agama/ Office of Religious Affairs (KUA), Forum Kerukunan Umat Beragama/ Religious Harmony Forum (FKUB), Majelis Ulama Indonesia/Indonesian Council of Religious Scholars (MUI) and sub-district and village governments are trying to take the path of family deliberation. It is practicable because the village culture is friendly and highly respectful of religious leaders or leaders, which makes it easy for all parties in conflict to join dialogue through family friendly deliberations.

The handling of these cases tends to be different from communal religious conflicts in urban areas. Resolution through power with the security apparatus approach dominates in urban areas such as communal conflicts in the case of the church construction. As there was a mass mobilisation in the form of Muslim demonstrations, legal and secure ways were selected to resolve the case. Finally, the government carried out mediation. The case occurred because of the construction of worship places in Bandung City, Cimahi City, Bekasi City and Bogor City.

Thus, the given explanation shows that various religious conflicts in West Java cannot be separated from the sociodemographic conditions of each region. The rural sociodemographic conditions that tend to be homogeneous effect the form of religious conflict towards the internal sectarianism of Muslims. It is different from the urban socio-demographic conditions, which tend to be heterogeneous. So, communal conflicts between religions, especially Muslim-Christian 
dominated the religious conflicts in urban areas. This study emphasises the importance of differentiating the study of religious conflict in a society based on socio-demographic conditions, which in the discipline of sociology distinguish diametrically between rural and urban sociology (Lobao 2007; Sassen 2007).

\section{Conclusion}

Indonesia is a large country covering many ethnic groups with religious background. This diversity is spread in various regions, both in urban and rural areas. Therefore, observing the occurrence of various religious conflicts in Indonesia over the last two decades, it is important to consider not only the diversity of ethnic and religious backgrounds but also the place of residence of ethnic and religious groups in urban and rural areas. The research data from 11 regencies and cities in West Java shows that there are important differences in the characteristics of rural (kabupaten) and urban (kotamadya) areas that affect the different patterns of conflict that develop in both the regions. Regency areas generally have a pattern of internal religious conflict amongst Muslims, as seen in disputes between sects or religious understandings in Islam. Homogeneous rural social conditions affect forms of internal conflicts. They are different from the urban areas that are dominated by communal conflicts between Muslims and Christians, especially in the case of the construction of worship places. Heterogeneous urban social conditions tend to have an impact on the communal forms of conflict. These different conflict patterns also affect the way of handling the conflict. In rural areas, dialogue between religious leaders and local communities is the way to handle internal Muslim conflicts. In contrast, in urban areas, resolution through power line with the security approach of the security forces is the way to handle communal religious conflicts in dealing with cases of building worship places.

\section{Acknowledgements}

The author would like to thank various parties who have provided support and convenience in the process of writing this article. Reference support and warm discussion has been a tremendous energy for the completion of this article.

\section{Competing interests}

The author declares that he has no financial or personal relationships that may have inappropriately influenced him in writing this article.

\section{Author's contributions}

A.N.J. is the sole author of this research article.

\section{Ethical considerations}

This article followed all ethical standards for research without direct contact with human or animal subjects.

\section{Funding information}

This research received no specific grant from any funding agency in the public, commercial or not-for-profit sectors.

\section{Data availability}

Data sharing is not applicable to this article as no data were created or analysed in this study.

\section{Disclaimer}

The views and opinions expressed in this article are those of the author and do not necessarily reflect the official policy or position of any affiliated agency the author.

\section{References}

Ali, M., 2013, 'Peran Pemerintah Daerah dan Kantor Kementerian Agama Provins Jawa Barat Dalam Pemeliharaan Kerukunan Umat Beragama', in B.A. Hakim (ed.), Peran Pemerintah Daerah dan Kantor Kementerian Agama Dalam Pemeliharaan Kerukunan Umat Beragama, pp. 246-267, Puslitbang Kehidupan Keagamaan Badan Litbang dan Diklat Kementerian Agama RI, Jakarta.

Ali Fauzi, I., Alam, R.H. \& Panggabean, S.R., 2009, Pola-pola Konflik Keagamaan di Indonesia (1990-2008), Yayasan Wakaf Parama-dina, MPRK-UGM dan The Asia Foundation, Jakarta.

Azra, A., 1999, Konteks Berteologi di Indonesia: Pengalaman Islam, Paramadina, Jakarta.

Bagir, Z.A., 2014, 'Advocacy for religious freedom in democratizing Indonesia', The Review of Faith \& International Affairs 12(4), 27-39. https://doi.org/10.1080/155 70274.2014.976084

Burhani, A.N., 2014, 'Treating minorities with fatwas: A study of the Ahmadiyya community in Indonesia', Contemporary Islam 8(3), 285-301. https://doi org/10.1007/s11562-013-0278-3

Burhani, A.N., 2020, “It's a Jihad": Justifying violence towards the Ahmadiyya in Indonesia', TRaNS: Trans -Regional and -National Studies of Southeast Asia 9(1) 99-112.

Coser, L., 1956, The functions of social conflict, Free Press, New York, NY.

CRCS, 2011, Laporan Tahunan Kehidupan Beragama di Indonesia 2010, Center for Religious and Cross-Cultural Studies, Gadjah Mada University, Yogyakarta.

CRCS, 2013, Laporan Tahunan Kehidupan Beragama di Indonesia 2012, Center for Religious and Cross-Cultural Studies, Gadjah Mada University, Yogyakarta.

Dandirwalu, R. \& Rehy, H.Y., 2020, 'Tahuri: Symbol of the Christian-Muslim community peace in Tehoru and Telutih, Central Maluku, Indonesia', Wawasan: Jurnal IImiah Agama dan Sosial Budaya 5(1), 67-76. https://doi.org/10.15575/jw.v5i1.8071

Djelantik, S., 2006, 'Terrorism in Indonesia: The emergence of West Javanese terrorists', International Graduate Student Conference Series, East-West Center, Honolulu.

Horikoshi, H., 1987, Kyai dan Perubahan Sosial, transl. U.B. dan A.M. Sunrawa, P3M, Jakarta.

Iqbal, M., 2015, Praktik Pengelolaan Keragaman di Indonesia Kontestasi dan Koeksistensi, CRCS-UGM, Yogyakarta.

Kustini, K., 2009, Efektifitas Sosialisasi Peraturan Bersama Menteri Nomor 9 dan 8 Tahun 2006, Balitbang Departemen Agama RI, Jakarta.

Lobao, L., 2007, 'Rural sociology', in C.D. Bryant \& D.L. Peck (eds.), 21st century sociology: A reference handbook, pp. 465-475, Sage, Los Angeles, CA.

Makin, A., 2019, 'Returning to the Religion of Abraham: Controversies over the Gafatar Movement in Contemporary Indonesia', Islam and Christian-Muslim Relations 30(1), 87-104. https://doi.org/10.1080/09596410.2019.1570425

Marshall, P., 2018, 'The ambiguities of religious freedom in Indonesia', The Review of Faith \& International Affairs 16(1), 85-96. https://doi.org/10.1080/15570274.201 8.1433588

Mudzakkir, A., 2008, 'Islam Priangan: Pergulatan Identitas dan Politik Kekuasaan', Tashwirul Afkar 26, 64-85.

Nasikun, 1986, Sistem Sosial Indonesia, Rajawali Press, Jakarta.

Newland, L., 2000, 'Under the banner of Islam: Mobilising religious identities in West Java', The Australian Journal of Anthropology 11(3), 199-222. https://doi. org/10.1111/j.1835-9310.2000.tb00056.x

Nurdin, A.A. \& Kharlie, A.T., 2019, 'Sunni and Shiite political thought of Islam state relationship: A comparison between Abdurrahman Wahid of Indonesia and Ayatollah Khomeini of Iran', Journal of Asian Social Science Research 1(1), 27-45. https://doi.org/10.15575/jassr.v1i1.5

Rumadi, R., 2007, 'Mengawal Pluralisme di Tengah Kegamangan Negara', in A. Suaedy (ed.), Politisasi Agama dan Konflik Komunal; Beberapa Isu Penting di Indonesia, pp. 1-17, The Wahid Institute, Jakarta. 
Sassen, S., 2007, 'Urban sociology in the 21st century', in C.D. Bryant \& D.L. Peck (eds.), 21st century sociology: A reference handbook, pp. 476-486, Sage, Los Angeles, CA.

Scherpen, B., 2011, 'Enforcing religious freedom in Indonesia: Muslim elites and the Ahmadiyah controversy after the 2011 Cikeusik Clash', in K. Van Dijk \& N.J.G. Kaptein (eds.), Islam politics and change: The Indonesian experience after the fall of Suharto, pp. 103-130, Leiden University Press, Leiden.

Setara Institute, 2014, Stagnasi Kebebasan Beragama: Laporan Kondisi Kebebasan Beragama/Berkeyakinan di Indonesia Tahun 2013, Pustaka Masyarakat Setara, Jakarta.

Setara Institute, 2016, Laporan Tengah Tahun Kondisi Kebebasan Beragama/ Berkeyakinan di Indonesia Januari-Juni 2016, Setara Institute, Jakarta.

Stolley, K.S., 2005, Basics of sociology, Greenwood Press, Westport, CT.

Sulistio, Y., 2018, 'Peristiwa konflik Agama di Bekasi: Studi kasus penolakan peribadatan Gereja HKBP Filadelfia di Desa Jejalen Jaya tahun 2007-2012', PhD dissertation, UIN Sunan Gunung Djati Bandung.
Syarif, D., Zulkarnain, I. \& Sofjan, D., 2017, 'Anti Shi'ism in Indonesia: Genealogy, development, and methods', Harmoni 16(1), 24-37. https://doi.org/10.32488/ harmoni.v16i1.54

Syukur, A., 2011, 'Islam, Etnisitas dan Politik Identitas: Kasus Sunda', dalam Miqot (Jurnal Ilmu-ilmu Keislaman) 35(2), 407-426. https://doi.org/10.30821/ miqot.v35i2.151

The Wahid Institute, 2015, Laporan Akhir Tahun Kebebasan Beragama/Berkeyakinan 2015, The Wahid Institute, Jakarta.

Toennies, F., 1963, Community and society, Harper and Row, New York, NY.

Van Bruinessen, M., 1999, Rakyat Kecil, Islam dan Politik, Yayasan Bentang Budaya, Yogyakarta.

Van Bruinessen, M., 2004, 'Gerakan Sempalan di Kalangan Umat Islam Indonesia: Latar Belakang Sosial Budaya', in A. Gunawan (ed.), Artikulasi Islam Kultural dar Tahapan Moral ke Periode Sejarah, pp. 206-236, Raja Grafindo Persada, Jakarta.

Zulkifli, 2009, 'The struggle of the Shi' is in Indonesia', PhD thesis, Leiden University. 